\title{
PEMBERDAYAAN GURU-GURU SMA MELALUI PELATIHAN TEKNIK MENULIS ILMIAH POPULAR DI MATARAM, NUSA TENGGARA BARAT
}

\author{
Agus Wibowo', ${ }^{1)}$ Karuniana Dianta $\mathbf{A S}^{2)}$, Haryo Kuncoro ${ }^{3)}$ \\ Fakultas Ekonomi, Universitas Negeri Jakarta \\ E-mail: agus-wibowo@unj.ac.id ${ }^{1)}$, diantasebayang@gmail.com²), har_kun@feunj.ac.id ${ }^{3)}$
}

\begin{abstract}
Training activities in West Mataram City, West Nusa Tenggara, aimed at: (1) to provide understanding among the senior high school teachers in Mataram City west Nusa Tenggara related subjects popular scientific writing, and the publication in mass media; (2) to train the senior high school teachers in Mataram west Nusa Tenggara related writing variety of scientific popular, so that they have a skill in this field. Target by the people of this activity is the senior high school teachers in Mataram City, West Nusa Tenggara, as many as 20 people. The activity was done in two important matters that are strongly associated with the popular writing techniques, which is the characteristic of scientific writing popular and strategies pierce the mass media. These are the activities of 20 May 2017. Early sessions, participants related to the understanding of articles, articles and scientific articles are popular. Next session, teachers learned how to write the interesting and lure editor. Instructors peel completed how to make leads but also tempting editors to choose articles and puts it. Based on the results of the training, the scientific writing of the article a supporting an increase in professional competence.
\end{abstract}

Keyword: Technique Writing, Popular Scientific

\section{ABSTRAK}

Kegiatan Pelatihan teknik menulis ilmiah populer bagi guru-guru SMA di Kota Mataram, Nusa Tenggara Barat, bertujuan: (1) untuk memberikan pemahaman kepada para guru SMA di Kota Mataram Nusa Tenggara Barat terkait aneka teknik menulis ilmiah populer, dan celah-celah publikasi di media massa; (2) untuk melatih para guru SMA di Kota Mataram Nusa Tenggara Barat terkait menulis ragam ilmiah populer, sehingga mereka memiliki keterampilan pada bidang tersebut. Khalayak sasaran dari kegiatan ini adalah para guru SMA di Kota Mataram, Nusa Tenggara Barat, sebanyak 20 orang. Kegiatan ini dilakukan dalam dua materi penting yang sangat terkait dengan teknik penulisan ilmiah populer, yaitu karakteristik tulisan ilmiah populer dan strategi menembus media massa. Kegiatan ini dilakukan selama satu hari, yaitu tanggal 20 Mei 2017. Pada sesi awal, peserta diberikan pemahaman terkait apa itu artikel, artikel ilmiah dan artikel ilmiah populer. Pada sesi selanjutnya, para guru diajari bagaimana mengemas tulisan menjadi menarik dan memikat redaktur. Instruktur mengupas tuntas bagaimana membuat lead yang tidak hanya menarik, tetapi juga menggoda redaktur untuk memilih artikel dan menerbitkannya. Berdasarkan hasil pelatihan yang sudah dilakukan didapat beberapa kesimpulan di antaranya para guru sudah memiliki pemahaman dan terampil menulis artikel ilmiah populer sebagai penunjang peningkatan kompetensi profesionalisme mereka.

Kata Kunci: teknik menulis, ilmiah populer

\section{PENDAHULUAN}

\section{A. Analisis Situasi}

Peraturan Menteri (Permen) PAN dan Reformasi Birokrasi (PAN-RB) No 16 Tahun 2009 tentang angka kredit, menegaskan bahwa Angka kredit adalah kinerja guru yang diwujudkan dalam angka. Jadi angka kredit itu menunjukkan kinerja guru profesional. Secara lengkap, angka kredit adalah satuan nilai dari tiap butir kegiatan dan/atau akumulasi nilai butir-butir kegiatan yang harus dicapai oleh seorang guru, dalam rangka pembinaan karier 1 | Jurnal Sarwahita Vol. 14 No. 01 Tahun 2017 kepangkatan dan jabatannya. Angka kredit itu juga berhak dikumpulkan oleh setiap guru. Guru dari jenis apa pun.

Selanjutnya dalam Permen PAN-RB Nomor 16 tahun 2009 tentang Jabatan Fungsional Guru dan Angka Kredit, secara rinci disebutkan: kenaikan golongan dari IIIa ke IIIb paling seidikit tiga angka kredit dari subunsur pengembangan diri. Dari IIIb ke IIIc paling sedikit empat angka kredit dari subunsur publikasi ilmiah. Dari IIIc ke IIId dibutuhkan minimal 6 angka kredit dari 
subunsur publikasi ilmiah. Darai IIId ke IVa dibutuhkan minimal delapan angka kredit dari subunsur publikasi ilmiah. Dari IVa menuju $\mathrm{IVb}$ butuh 12 angka kredit dari subunsur publikasi ilmiah. Dari IVb menuju IVc butuh 12 angka kredit dari subunsur publikasi iolmiah. Dari IVc ke IVd butuh 14 angka kredit darisubunsur publikasi ilmiah. Dari IVd ke IVe butuh minimal 20 angka kredit dari subunsur publikasi ilmiah. Rincian penilaian ada di lampiran berjudul Rincian Kegiatan Guru dan Angka Kredit. Jadi ada dua unsur kegiatan guru, yakni unsur utama dan unsur penunjang. Unsur utama ada tiga, yakni pendidikan, pembelajaran bimbingan dan tugas tertentu, dan ketiga adalah Pengembangan Keprofesian Berkelanjutan (PKB). Unsur penunjang adalah gelar yang tidak sesuai, penghargaan, pelaksaan kegiatan yang mendukung tugas guru (misal menjadi tutor, pelatih, atau instruktur).

Adapun menulis artikel tercantum dalam unsur ketiga, subunsur kedua, butir g, yang berbunyi: "Membuat artikrel ilmiah populer bidang pendidikan formal dan pembelajaan pada satuan pendidikannya tingkat nasional" (Nilai 2) dan utuk tingkat provinsi $(1,5)$. Dengan demikian, jika seorang guru tulisan ilmiahnya bisa tembus media nasional sekali saja, maka yang bersangkutan dapat poin 2 . Selanjutnya jika sebulan hanya mampu menulis minimal sekali saja, maka akan dapat 12 poin. Hal itu bisa dilipatgandakan bila sebulan bisa dua kali (yakni 24 poin). Hal itu bis melampaui pendidikan dan latihan fungsional yang memakan waktu 960 jam atau empat bulan! Bisa juga dibandingkan dengan keribetan lain. Nilai satu artikel sepuluh kali lebih tingi ketimbang menjadi peserta loka karya $(0,2)$. Itu berarti, ketimbang duduk mengantuk di lokakarya, guru bisa menulis artikel di rumah sambil makan camilan ringan, dan setelah selesai dikirim lewat email. Ini yang dimaksud bekerja santai namun cerdas.

Menulis membutuhkan kemampuan yang spesifik terkait dengan sebuah maalah yang diangkat. Kemampuan yang dimaksud adalah kemampuan menganalisis, menafsirkan, memberikan saran-saran. Kemampuan itu dapat dilihat dalam dua hal. Pertama, kemampuan yang sudah tersedia. Kedua kemampuan yang harus digali. Kemampuan pertama diperoleh melalui belajar dari waktu ke waktu sehingga kemampuan itu sudah siap kapan pun. Kemampuan tersebut diperoleh melalui bangku kuliah, disiplin yang tak kenal waktu, atau melalui belajar yang terusmenerus tentang banyak hal dengan cara tertentu. Contoh kemampuan yang sudah tersedia adalah hasil kuliah, disiplin menulis tiap pagi dan sore, kursus menulis, dan masih banyak lagi.

Kemampuan kedua, kemampuan yang harus digali, adalah kemampuan menggabungkan data-data yang berserakan terkait dengan masalah. Persoalan yang diangkat tidak selalu mendapatkan perspektif yang tepat atas suatu soal. Karena itu, diperlukan kemampuan yang tepat untuk menyelesaikan masalah itu. Kita perlu melakukan pencarian di dunia maya, membuka-buka bank data, sehingga memerlukan ketekunan yang terlatih.

Menurut Sardi (2016), ada beberapa kesulitan yang menyebabkan guru enggan menulis. Pertama, guru merasa tidak memahami tujuan mereka menulis. Menulis merupakan suatu proses pembelajaran. Baik itu untuk diri penulis maupun orang lain. Apabila seorang mampu menulis, tujuan utamanya adalah agar tulisan itu dibaca oleh orang lain. Orang lain yang mulanya tidak tahu, menjadi tahu. Dengan demikian, diri penulis akan teraktualisasi (dikenal), diakui eksistensinya dan tentu saja akan merasa bangga dan puas yang tidak bisa diukur nilainya. Jika hasil tulisan dimuat di suatu surat kabar, tentu akan mendapat penghargaan dan imbalan yang layak. Jadi secara ekonomis, bisa menambah penghasilan bagi orang yang berhasil menulis. Apabila seorang guru mau dan mampu mendasari semangatnya dengan berpijak dari tujuan menulis, maka hasil tulisannya akan berkembang dan berbobot.

Kedua, guru enggan untuk belajar dan membaca. Banyak guru ingin bisa memiliki keterampilan menulis, namun banyak pula yang tidak mau tahu, bagaimana proses untuk 
menjadi seorang penulis tersebut. Salah satu usaha untuk menjadi penulis, harus mau belajar kepada siapa saja dan tentang berbagai hal sebagai penunjang terbentuknya sebuah tulisan. Salah satu bentuk belajar yang dilakukan penulis adalah membaca. Dengan belajar dan membaca, penulis akan memiliki bahan yang luas untuk diolah menjadi sebuah tulisan. Sayang, banyak guru merasa enggan belajar dan membaca. Merasa pengetahuan dan keterampilan yang sekarang dimilikinya sudah banyak. Mereka mengetahui bahwa ilmu itu selalu berkembang, tetapi kurang mau menyikapi perkembangan ilmu dengan belajar dan membaca. Apalagi menulis?

Ketiga, tidak ada waktu untuk menulis. Dengan banyaknya beban dan tanggungjawab yang ada, orang merasa tidak punya waktu dan kesempatan lagi untuk menulis. Benarkah demikian? Perlu disadari bahwa Tuhan itu Maha Adil. Tuhan memberikan waktu yang sama kepada semua ciptaan-Nya. Jika ada orang beralasan tidak punya waktu untuk menulis, mungkin mempunyai anggapan bahwa menulis itu butuh waktu khusus. Pada hal, menulis itu bisa dilakukan kapan dan di mana saja. Terlebih untuk jaman modern sekarang ini, alat untuk menulis semua serba canggih. Tugas dan tanggungjawab guru di mana saja sama. Banyak guru yang berhasil menulis. Hal ini menunjukkan bahwa mereka (termasuk kita) masih punya waktu untuk menulis. Tinggal bagaimana kita mengatur atau mengelola waktu untuk menulis.

Keempat, tidak tahu apa yang mesti ditulis. Menulis tidak jauh berbeda dengan berbicara. Menulis itu berbicara yang dituangkan dalam bentuk tulisan. Jika bingung akan menulis tentang apa, tulis saja tentang apa yang sedang kita bicarakan. Atau apa yang sekarang kita rasakan dan alami. Sebagai seorang guru tentu sering mendengar, melihat, dan merasakan suatu permasalahan yang beraneka macam. Tidak perlu bingung akan apa yang bisa dijadikan sebagai bahan untuk ditulis. Ya, yang didengar, dilihat dan dirasakan itulah dituangkan dalam bentuk tulisan.

Kelima, sulit menentukan ragam dan bentuk tulisan. Jika dalam menulis kita terpancang dengan teori tentang ragam dan bentuk suatu tulisan, maka kita akan terskeptis (terbatasi). Tidak merasa bebas menuangkan tulisan. Pada hal, menulis itu suatu kebebasan berekspresi menuangkan ide dan gagasan. Oleh sebab itu, salah kiranya jika kita sendiri yang membatasi diri. Ingin menulis cerita pendek, pantun, opini, future, dan sebagainya. Sebagai seorang guru mestinya kita sadar bahwa manusia (kita) itu memiliki jiwa untuk berekspresi dalam menuangkan ide dan gagasannya. Jika kita ingin menulis, mulai saja menulis. Jangan berfikir hasil tulisannya ini nanti berbentuk apa. Biarlah orang lain yang membaca tulisan kita yang akan memberikan penilaian tentang ragam dan bentuknya.

Keenam, tidak tahu cara mengirim tulisan. Tujuan utama menulis adalah agar tulisannya dibaca oleh orang lain. Jika menginginkan yang membaca tulisan itu banyak orang, kirimkan ke surat kabar agar dimuat. Sayangnya, tidak semua orang tahu bagaimana cara mengirimkan tulisannya. Pada hal ini mudah. Tulis sebuah surat yang ditujukan kepada redaksi yang diinginkan. Isi surat, memohon agar tulisan dimuat. Pada akhirnya, sebagai seorang guru hendaknnya jangan gagap teknologi. Dengan kemampuan dan ketarampilan yang kita miliki, mari kita gunakan untuk mengembangkan diri dengan menuangkan ide dan gagasan kita dalam bentuk tulisan.

Berdasarkan uraian-uraian di atas dapat disimpulkan bahwa pelatihan menulis ilmiah populer mendesak dilakukan bagi guru-guru SMA di Kota Mataram, Nusa Tenggara Barat. Ini menjadi penting, agar para guru memiliki keterampilan menulis, yang pada muaranya bisa menambah angka kredit kepangkatan, mengharumkan nama sekolah, memperluas wawasan dan yang paling utama meningkatkan profesionalisme keguruan di bidang pendidikan. Kegiatan pelatihan menulis ilmiah populer ini, juga membekali para guru dengan keterampilan dan kecakapan hidup (liveskills), yang tidak saja berguna bagi guru tetapi juga anak didik mereka. Data dan fakta sebagaimana diuraikan, menjadi dasar untuk melakukan pengabdian masyarakat 
dengan judul: "Pelatihan Teknik Menulis Ilmiah Populer Bagi Guru-Guru SMA Di Kota Mataram, Nusa Tenggara Barat."

\section{B. Perumusan Masalah}

1. Idenfitikasi Masalah

Berdasarkan uraian di atas, maka dapat diidentifikasi terdapat permasalahan sebagai berikut: (a) Guru merasa tidak memahami tujuan mereka menulis; (b) Guru tidak tahu cara mengirim tulisan; (c) Guru tidak tahu apa yang mesti ditulis; (d) Guru tidak ada waktu untuk menulis, dan (e) Guru sulit menentukan ragam dan bentuk tulisan

\section{Rumusan Masalah}

Selanjutnya, berdasarkan analisis situasi sebagaimana telah diuraikan di atas, maka membekali para guru dengan keterampilan menulis ilmiah populer merupakan solusi tepat. Pelatihan teknik menulis ilmiah populer menjadi penting, bukan saja agar para guru terampil menulis, tetapi juga muaranya menular bahkan menginspirasi pada anak didik mereka. Keuntungan dari pelatihan ini bukan hanya urgen tetapi juga signifikan bagi karir serta profesionalisme guru. Diharapkan, selepas pelatihan tersebut para guru tidak hanya terampil tetapi juga berani mempublikasikan tulisan mereka baik di koran skala lokal maupun nasional.

\section{Tujuan Masalah}

Kegiatan pengabdian masyarakat ini bertujuan untuk:

a. Memberikan pemahaman kepada para guru SMA di Kota Mataram Nusa Tenggara Barat terkait aneka teknik menulis ilmiah populer, dan celah-celah publikasi di media massa;

b. Melatih para guru SMA di Kota Mataram Nusa Tenggara Barat terkait menulis ragam ilmiah populer, sehingga mereka memiliki keterampilan pada bidang tersebut.

\section{Manfaat Kegiatan}

Adapun manfaat yang diperoleh dari kegiatan ini adalah:

1. Peserta

a. Guru-guru SMA di Kota Mataram, Nusa Tenggara Barat, memiliki pemahaman terkait apa itu tulisan ilmiah populer, strategi menggali ide, menganyam data dan fakta, dan keterampilan menulis ragam ilmiah populer.

b. Guru-guru SMA di Kota Mataram, Nusa Tenggara Barat, termotivasi untuk menulis ilmiah populer dan berani untuk mempublikasikannya baik di media level lokal, maupun media massa level nasional.

2. Tim Pengabdian Masyarakat

a. Memberikan kontribusi pengetahuan dan pengalaman kepada masyarakat khususnya guru-guru SMA di Kota Mataram, Nusa Tenggara Barat sesuai dengan kompetensi yang dimiliki oleh instruktur;

b. Terbinanya hubungan yang baik antara guru-guru SMA di Kota Mataram, Nusa Tenggara Barat dan Stakeholder di wilayah Nusa Tenggara Barat dengan Universitas Negeri Jakarta (UNJ).

\section{KAJIAN PUSTAKA}

\section{A. Tulisan Ilmiah Populer}

Tidak banyak kaum intelektual yang terbiasa dengan tulisan ilmiah populer. Mereka lebih terbiasa mempergunakan tulisan dengan ragam ilmiah. Tulisan ilmiah menurut Brotowidjoyo (dalam M Ekosusilo,1995:11), merupakan tulisan ilmu pengetahuan yang tidak hanya menyajikan fakta tetapi juga data, dan ditulis dengan berpatokan pada metodologi penulisan yang baik dan benar. Tulisan ilmiah, lanjut Brotowidjoyo, disusun bukan sekedar opini atau pendapat penulis saja, tetapi juga didasari oleh hasil pengamatan, peninjauan, penelitian tertentu dengan sistematika bahasa dan isi yang santun, serta dapat dipertanggungjawabkan kebenarannya secara ilmiah.

Jurnal Sarwahita Vol. 14 No. 01 Tahun 2017 | 4 
Karena sifatnya yang ilmiah, tulisan model ini memiliki ciri-ciri sebagai berikut:

1. Tulisan ilmiah harus objektif. Artinya, fakta dan data yang dipaparkan atau diungkap berdasarkan atas kondisi yang senyatanya atau sebenarnya. Data dan fakta yang dipaparkan juga bukan hasil manipulasi, rekayasa atau dikondisikan. Selanjutnya setiap pernyataan atau simpulan dalam tulisan ilmiah disertai dengan bukti-bukti yang valid dan bisa dipertanggungjawabkan. Pembaca yang ingin menguji kebenaran data dalam tulisan ilmiah, bisa mengecek atau melakukan validasi. Dengan demikian, sebuah tulisan di mana paparan fakta dan data tidak sesuai dengan kondisi di lapangan, maka tidak bisa disebut sebagai tulisan ilmiah.

2. Tulisan ilmiah itu sistematis. Artinya, tulisan ilmiah ini mengikuti pola sistematika tertentu seperti klasifikasi, kausalitas, deduktif-induktif dan sebagainya. Sistematika dengan pola tertentu ini selain agar tidak berbelit-belit juga memudahkan pembaca mengikuti alur paparan yang diuraikan dalam tulisan ilmiah.

3. Tulisan ilmiah itu netral. Artinya, uraianuraian dari tulisan ilmiah ini bebas dari unsur kepentingan tertentu. Misalnya kepentingan pribadi penulis, maupun kelompok yang bersangkutan. Dengan demikian, dalam tulisan ilmiah uraian dan pernyataan yang sifatnya persuasif serta provokatif sangat dihindari.

4. Tulisan ilmiah itu menyajikan fakta. Sebagaimana telah diuraikan sebelumnya, paparan dalam tulisan ilmiah itu berisi fakta bukan emosi atau perasaan subjektif penulis. Dengan kata lain, setiap pernyataan, uraian, atau simpulan dalam karya ilmiah harus faktual, yaitu menyajikan fakta. Oleh karena itu, pernyataan atau ungkapan yang emosional (menggebu-gebu seperti orang berkampanye, perasaan sedih seperti orang berkabung, perasaan senang seperti orang mendapatkan hadiah, dan perasaan marah seperti orang bertengkar) sangat dihindarkan.
5. Tulisan ilmiah itu logis. Artinya, uraianuraian dalam tulisan ilmiah selalu menggunakan pola nalar deduktif maupun induktif. Jika tulisan ilmiah itu disusun untuk menyimpulkan suatu fakta atau data, maka digunakan pola induktif. Sebaliknya, jika tulisan tersebut bermaksud membuktikan suatu teori atau hipotesis, maka digunakan pola deduktif.

6. Uraian-uraian dalam tulisan ilmiah itu tidak pleonastis. Artinya, kata-kata yang dipergunakan dalam tulisan ilmiah tidak berlebihan, hemat atau irit. Dengan kata lain, kalimat-kalimat dalam tulisan ilmiah selalu "to the point."

Adapun yang dimaksud dengan tulisan ilmiah populer adalah tulisan yang bentuk, isi, dan bahasanya menggunakan kaidah keilmuan, tetapi disajikan dalam bahasa yang santai, menarik, mengalir, dan mudah dipahami masyarakat awam. Menurut Dalman (2012:156), tulisan ilmiah populer ini lebih banyak diciptakan dengan jalan menyadur, mengutip, dan meramu informasi dari berbagai tulisan orang lain, daripada menulis murni gagasan, pendapat, dan pernyataan sendiri. Artinya, karya tulis ilmiah populer lebih cocok disebut sebagi tulisan daripada karangan. Seperti yang dipaparkan di atas, secara otomatis akan ada proses reduksi makna ilmiah dari makna aslinya ketika digandengkan dengan kata populer. Namun meski melangalami reduksi, kata-kata ilmiah tetap menggambarkan pertanggungjawaban penulisnya secara ilmiah dengan pencantuman sumber rujukan.

Terkait dengan tulisan ilmiah populer ini, sebagaimana telah diuraikan sebelumnya, tidak banyak kaum intelektual kita yang menguasainya. Diperlukan latihan khusus yang konsisten, dan penguasaan pilihan kata yang banyak. Berdasarkan pengalaman penulis, untuk menguasai ragam tulisan ilmiah populer ini, diperlukan keseriusan, ketekunan dan belajar secara konsisten. Terutama tulisan artikel di media massa

\section{B. Karakteristik Tulisan Ilmiah Populer}

Ciri-ciri menonjol dari tulisan ilmiah populer menurut Hakim (2004:57), di 
antaranya: Pertama, bahan uraian berupa fakta yang objektif. Artinya, meski disajikan dengan bahasa yang sederhana, unsur objektivitas penulis tetap menjadi pegangan utama. Kedua, tulisan ilmiah populer disajikan dengan menggunakan bahasa yang cermat, tidak terlalu formal tapi tetap taat asas, disusun secara sistematis; tidak memuat hipotesis. Ketiga, sikap penulis tidak memancing pertanyaan-pertanyaan yang meragukan. Dan keempat, penyimpulan dilakukan dengan memberikan fakta.

Berdasarkan pendapat-pendapat sebagaimana telah diuraikan dapat kita ketahui bahwa perbedaan menonjol antara tulisan ilmiah dan ilmiah populer terletak pada cara penyajiannya. Tulisan ilmiah murni (skripsi, tesis, desertasi, dan lain-lain) terletak pada bahasa penyampaian yang digunakan. Karya tulis ilmiah murni ditampilkan dalam bahasa baku dan sangat terikat dengan kaidah bahasa Indonesia resmi. Sementara ilmiah populer ditampilkan dengan bahasa yang lebih luwes, serta dapat dipahami masyarakat umum.

Dari segi topik bahasan, tulisan ilmiah populer cenderung membahas permasalahan yang berkaitan dengan masyarakat di sekitarnya. Berbeda dengan karya tulis ilmiah murni yang lebih sering berkutat dalam bidang ilmiah yang jauh dari jangkauan masyarakat awam. Sarana untuk mempublikasikan karya ini hampir tidak ada yang berdiri sendiri secara utuh. Biasanya dalam suatu media massa, karya ini dipadukan dengan karya tulis non-ilmiah. Contoh karya ilmiah populer ini biasanya kita jumpai di majalah, tabloid, dan koran.

Karena sifatnya yang ringan, aktual dan penyajian bahasa yang sesuai dengan kehidupan sehari-hari, jenis tulisan ilmiah populer saat ini mendapat tempat di masyarakat. Bahkan, tulisan ilmiah populer ini juga menjadi ukuran kepakaran serta kedalaman ilmu seseorang. Itulah sebabnya banyak beberapa profesor saat ini intens menulis dengan model ilmiah populer tersebut.

Sebagaimana telah diuraikan sebelumnya, Menulis artkel ada di unsur ketiga, subunsur kedua, butir g. Bunyinya: "Membuat artikrel ilmiah populer bidang pendidikan formal dan pembelajaan pada satuan pendidikannya tingkat nasional" (Nilai 2 ). Untuk tingkat provinsi $(1,5)$. Jadi kalau kita tembus media nasional sekali saja, maka kita dapat popin 2. jika sebulan cuma menulis sekali saja, maka akan dapat 12 poin. Hal itu bisa dilipatgandakan bila sebulan bisa dua kali (yakni 24 poin). Hal itu bis melampaui pendidikan dan latihan fungsional yang memakan waktu 960 jam atau empat bulan! Bisa juga dibandingkan dengan keribetan lain. Nilai satu artikel sepuluh kali lebih tingi ketimbang menjadi peserta loka karya $(0,2)$. Itu berarti, ketimbang duduk mengantuk di lokakarya, kita bisa menulis artikel di kafe sambil makan donut dan setelah selesai dikirim lewat email dengan jempol yang berlepotan cokelat. Namanya bekerja cerdas.

Selanjutnya, sebagai guru PNS, pemerintah melarang pekerjaan sampingan. Demikian pula guru dilarang masuk ke organisasi politik. Organisasi politik dan kerja sampingan adalah penghasilan tambahan, tetapi dilarang oleh Pemerintah. Menulis adalah pekerjaan sampingan yang tidak dilarang. Malah dianjurkan. Sudah dapat uang, dapat poin lagi. Bayangkan saja, bila satu bulan bisa menembus koran dua kali saja, maka honornya sekitar Rp 2,5 juta hingga Rp 3 juta. Angka tersebut lebih besar dari gaji pokok seorang guru lulusan S1 dengan masa kerja nol tahun. Padahal, menulis dua artikel dalam satu bulan tidak membutuhkan waktu sehari.

\section{MATERI DAN METODE}

\section{A. Metode Pemecahan Masalah}

Metode kegiatan ini adalah berupa pelatihan dan workshop, di mana para peserta belajar teori teknik menulis ilmiah populer. Melalui pelatihan ini diharapkan para guru SMA, Di Kota Mataram, Nusa Tenggara Barat, termotivasi dan tergugah untuk menulis, bahkan mempublikasikannya di media massa baik lokal maupun nasional. 


\section{B. Realisasi Pemecahan Masalah}

Pada sesi pertama, peserta diberikan pemahaman terkait apa itu artikel, artikel ilmiah dan artikel ilmiah populer. Instruktur secara detail mengupas terkait karakteristik artikel ilmiah populer dan di mana saja biasanya dipublikasikan. Instruktur juga memberikan motivasi agar para guru mau menulis, sebagai wujud pengembangan kompetensi profesional di samping penyebaran ide-ide terkait pendidikan kepada masyarakat. Menulis artikel ilmiah populer merupakan salah satu kiat mencerahkan masyarakat, khususnya terkait pendidikan yang menjadi bidang garap para guru seharihari.

Pada sesi kedua, peserta diperkenalkan pada teori perspektif. Melalui teori perspektif ini, para guru diajak memotret satu tema dengan menggunakan perspektif yang berbeda; seperti perspektif sosial, budaya, agama dan pendidikan. Melalui perspektif yang berbeda, para guru bisa mengulas sebuah tema tanpa harus takut hal sama sudah ditulis oleh penulis lain.

Pada sesi ketiga, para guru diajari bagaimana mengemas tulisan menjadi menarik dan memikat redaktur. Instruktur mengupas tuntas bagaimana membuat lead yang tidak hanya menarik, tetapi juga menggoda redaktur untuk memilih artikel dan menerbitkannya. Instruktur juga memberikan tips bagaimana membuat simpulan yang menarik dan persuasif, sehingga merangsang pembaca untuk melakukan apa yang menjadi ide penulis. Selain itu, instruktur juga memberikan kiat-kiat bagaimana mengirimkan artikel ke media massa baik nasional maupun lokal, beserta email redakturnya.

Sesi terakhir kegiatan adalah tanya jawab tentang hal-hal yang masih belum dipahami oleh peserta, atau sekedar berkonsultasi dan meminta tips sukses menembus media. Instruktur menjelaskan dengan gamblang bagaimana strategi dan ketahan-malangan untuk bisa tembus di media massa baik dalam lingkup lokal maupun nasional. Adapun materi kegiatan yang disampaikan serta instruktur pada program kegiatan ini dirangkum pada tabel 1 .

Tabel 1

Materi Kegiatan dan Instruktur

\begin{tabular}{|c|c|c|c|}
\hline NO & MATERI & INSTRUKTUR & WAKTU \\
\hline 1 & $\begin{array}{l}\text { Pembukaan, pengenalan } \\
\text { dan motivasi dasar-dasar } \\
\text { menulis }\end{array}$ & $\begin{array}{l}\text { Dr. Karuniana Dianta AS, } \\
\text { ME (Ketua) }\end{array}$ & 60 Menit \\
\hline 2 & $\begin{array}{l}\text { Teori Perspektif dan } \\
\text { Penggalian Ide }\end{array}$ & $\begin{array}{l}\text { Dr. Haryo Kuncoro, M.Si } \\
\text { (Anggota) }\end{array}$ & 80 Menit \\
\hline 3 & $\begin{array}{l}\text { Teknik menulis ilmiah } \\
\text { populer dan strategi } \\
\text { publikasi ke media massa }\end{array}$ & $\begin{array}{l}\text { Agus Wibowo, M.Pd } \\
\text { (Anggota) }\end{array}$ & 80 Menit \\
\hline 4 & Diskusi dan tanya jawab & $\begin{array}{l}\text { Dr. Karuniana Dianta AS, } \\
\text { ME, Dr. Haryo Kuncoro, } \\
\text { M.Si, Agus Wibowo, M.Pd }\end{array}$ & 80 Menit \\
\hline & Total Alokasi Waktu & & $\begin{array}{l}300 \text { Menit/ } \\
5 \text { Jam }\end{array}$ \\
\hline
\end{tabular}

\section{Khalayak dan Sasaran}

Kegiatan Pengabdian Masyarakat ini dilaksanakan pada hari Sabtu tanggal 20 Mei 2017 bertempat di Aula Gedung PGRI cabang 7 | Jurnal Sarwahita Vol. 14 No. 01 Tahun 2017
Kota Mataram, yang berlokasi di Jl. Kaktus No.8, Gomong, Selaparang, Kota Mataram, Nusa Tenggara Barat, 83126. Kegiatan pelatihan teknik menulis ilmiah populer bagi guru-guru SMA Di Kota Mataram, Nusa 
Tenggara Barat, berlangsung jam 08.30 13.00 WITENG.

\section{Waktu Pelaksanaan}

Pelaksanaan kegiatan Pelatihan Teknik Menulis Ilmiah Populer Bagi Guru-Guru SMA, Di Kota Mataram, Nusa Tenggara Barat. Peserta sebanyak 20 orang yang berasal dari guru-guru SMA di Kota Mataram, Nusa Tenggara Barat.

\section{HASIL DAN PEMBAHASAN}

Berdasarkan hasil observasi selama berlangsungnya kegiatan pelatihan Teknik Menulis Ilmiah Populer Bagi Guru-Guru SMA Di Kota Mataram, Nusa Tenggara Barat, dapat disimpulkan bahwa secara kualitatif telah terlaksana dengan efektif. Hal yang menjadi indikator keefektifan pelaksanaan kegiatan di antaranya, dari sisi peserta yang sangat serius dan antusias mengikuti jalannya pelatihan. Lebih dari itu, mereka juga berusaha mempraktikkan apa yang telah disampaikan narasumber. Selain itu, selama kegiatan pelatihan berlangsung, terjalin komunikasi interaktif, didukung oleh suasana yang kondusif, sehingga peserta dapat menguasai materi pelatihan dengan baik.

Komunikasi dengan peserta pelatihan pelatihan Teknik Menulis Ilmiah Populer Bagi Guru-Guru SMA Di Kota Mataram, Nusa Tenggara Barat, juga masih terus terbina. Hal ini ditandai dengan masih seringnya mereka meminta saran, pendapat serta motivasi terkait bagaimana menulis ilmiah populer yang baik dan menarik. Tidak jarang, mereka juga meminta salah satu pemateri untuk mengkoreksi hasil tulisan untuk dikirimkan ke media massa di Kota Lombok, Nusa Tenggara Barat.

Berdasarkan hasil pelaksanaan kegiatan Pelatihan Teknik Menulis Ilmiah Populer Bagi Guru-Guru SMA Di Kota Mataram, Nusa Tenggara Barat, maka dapat disimpulkan dua faktor penting yaitu faktor penunjang dan faktor penghambat. Faktor penunjang antara lain minat dan atusiasme peserta yang tinggi, serta tersedianya tempat pelatihan yang kondusif meski dari sisi kelengkapan terbatas.
Selanjutnya, pelatihan Teknik Menulis Ilmiah Populer Bagi Guru-Guru SMA Di Kota Mataram, Nusa Tenggara Barat ini juga mendapat respons serta dukungan dari segenap stakeholders pendidikan setempat. Itu ditandai dengan hadirnya Bapak Kepala Dinas Pendidikan Kota Lombok, yang menunggui hingga kegiatan tersebut paripurna. Selain Bapak Kepala Dinas Pendidikan Kota Lombok, para pengurus PGRI cabang Kota Lombok juga sangat antusias mengikuti kegiatan tersebut dari awal hingga paripurna. Mereka bahkan turut membantu mempersiapkan segala perlengkapan yang dibutuhkan dalam kegiatan tersebut.

Adapun faktor penghambat yang utama adalah masih awamnya para guru dengan ragam tulisan ilmiah populer. Mereka masih merasa asing dengan model tulisan tersebut, bahkan beberapa guru tidak mengetahui sama sekali. Hambatan selanjutnya adalah peserta pelatihan tidak membawa Notebook, sehingga praktik menulis hanya dilakukan secara manual. Mestinya, jika mereka membawa netbook, praktik penulisan ilmiah populer akan lebih efektif lagi karena pembicara bisa menunjukkan dengan jelas di mana letak kesalahan artikel yang sudah dibuat. Peserta pelatihan juga langsung bisa mengirimkan artikel yang sudah diedit oleh pembicara ke media lokal maupun nasional.

Selain tidak membawa netbook sebagian peserta pelatihan adalah kaum ibu yang usianya sudah tidak muda lagi, sehingga membutuhkan kesabaran ekstra untuk menjelaskan konsep-konsep atau hal-hal sulit terkait dengan penulisan ilmiah populer.

\section{KESIMPULAN DAN SARAN}

Berdasarkan uraian-uraian paragraf sebelumnya, serta berdasarkan observasi selama kegiatan, dapat disimpulkan bahwa hasil kegiatan Pelatihan Teknik Menulis Ilmiah Populer Bagi Guru-Guru SMA Di Kota Mataram, Nusa Tenggara Barat, adalah para guru memiliki pemahaman dan terampil menulis artikel ilmiah populer sebagai penunjang peningkatan kompetensi profesionalisme mereka. Diharapkan selepas kegiatan tersebut, para guru tergerak untuk 
menuangkan ide, konsep cerdas dan fakta aktual terkait pendidikan, serta mempublikasikan tulisan tersebut ke media massa-baik lokal maupun nasional.

Selanjutnya, jika budaya menulis di kalangan guru-guru SMA Kota Mataram itu terus tersemai dengan baik, maka bukan tidak mungkin akan menular ke anak didik mereka. Ke depan, akan banyak ide-ide pembaharuan pendidikan baik sifatnya lokal maupun nasional, tertoreh lewat tulisan-tulisan para guru SMA di Kota Lombok yang telah mengikuti kegiatan tersebut.

Berdasarkan hasil pelaksanaan kegiatan Pelatihan Teknik Menulis Ilmiah Populer Bagi Guru-Guru SMA Di Kota Mataram, Nusa Tenggara Barat, maka dapat disimpulkan dua faktor penting yaitu faktor penunjang dan faktor penghambat. Faktor penunjang antara lain minat dan atusiasme peserta yang tinggi, serta tersedianya tempat pelatihan yang kondusif meski dari sisi kelengkapan terbatas.

Selanjutnya, pelatihan Teknik Menulis Ilmiah Populer Bagi Guru-Guru SMA Di Kota Mataram, Nusa Tenggara Barat ini juga mendapat respons serta dukungan dari segenap stakeholders pendidikan setempat. Itu ditandai dengan hadirnya Bapak Kepala Dinas Pendidikan Kota Lombok, yang menunggui hingga kegiatan tersebut paripurna. Selain Bapak Kepala Dinas Pendidikan Kota Lombok, para pengurus PGRI cabang Kota Lombok juga sangat antusias mengikuti kegiatan tersebut dari awal hingga paripurna. Mereka bahkan turut membantu mempersiapkan segala perlengkapan yang dibutuhkan dalam kegiatan tersebut.

Diharapkan kegiatan ini terus dilanjutkan, sehingga dampak positifnya bisa dinikmati oleh para guru SMA di Kota Mataram, Nusa Tenggara Barat. Lebih dari itu, ke depan, diharapkan kegiatan sejenis lebih diefektifkan lagi, yang muaranya adalah peran Universitas Negeri Jakarta lebih nyata dan bermanfaat bagi guru SMA di Kota Mataram, Nusa Tenggara Barat.

\section{DAFTAR PUSTAKA}

Dalman. 2014. Keterampilan Menulis. Jakarta: PT. Raja Grafindo Persada.

Kresna Langit Hariadi. 2004. Mengarang Itu Gampang. Solo: Tiga Serangkai Pustaka Mandiri.

Madyo Ekosusilo. 1995. Pedoman Penulisan Karya Ilmiah. Semarang: Sahara Prize.

M. Arief Hakim. 2005. Kiat menulis Artikel di Media; Dari Pemula Sampai Mahir (Edisi Revisi). Bandung: Penerbit Nuansa Cendikia.

Mukayat D Brotowidjoyo. 1995. Penulisan Karangan Ilmiah. Jakarta: Akademi Presindo.

Peraturan Menteri Pendayagunaan Aparatur Negara dan Reformasi Birokrasi Nomor 46 tahun 2013 tentang perubahan atas peraturan menteri pendayagunaan aparatur negara dan reformasi birokrasi nomor 17 tahun 2013 tentang Jabatan Fungsional Dosen dan Angka Kreditnya.

Peraturan Menteri Negara Pendayagunaan Aparatur Negara dan Reformasi Birokrasi Nomor 16 tahun 2009 tentang Jabatan Fungsional Guru dan Angka Kreditnya.

Sardi. 2016. Sepuluh Alasan Mengapa Guru Enggan Menulis. Tersedia di: http://denbeisardi.blogspot.co.id/2016 /04/sepuluh-alasan-mengapa-guruenggan.html

Wardani. dkk. 2007. Teknik Menulis Karya Ilmiah. Jakarta: Universitas Terbuka.

Widjono. 2007. Bahasa Indonesia (Mata Kuliah Pengembangan Kepribadian di Perguruan Tinggi ). Jakarta : Grasindo 